\title{
PEMANFAATAN METODE PENGECEKAN PASIR ALTERNATIF (BY VOLUME) UNTUK MEMPERSINGKAT WAKTU PENERIMAAN DELIVERY PASIR PADA PERUSAHAAN BETON
}

\author{
N. Neni Triana \\ Program Studi Teknik Industri, Universitas Buana Perjuangan Karawang \\ Jl. HS. Ronggowaluyo Telukjambe Timur, Karawang 41361. \\ email: neni.triana@ubpkarawang.ac.id
}

\begin{abstract}
ABSTRAK
Penggunaan pasir merupakan bahan baku utama yang digunakan pada industri beton dan keberadaanya bergantung kepada sumber daya alam yang tidak bisa diperbaharui, sebagai bahan baku utama maka mutu pasir juga sangat berpengaruh terhadap kekuatan beton seperti pada penelitian sebelumnya "kadar lumpur mempengaruhi terhadap kuat tekan beton, semakin kecil kadar lumpur, maka kuat tekan beton dan berat jenis beton akan semakin tinggi"'(Purwanto, Yulita Arni Priastiwi, 2012), sehingga untuk mendapatkan kualitas pasir yg sesuai standar diperlukan proses pengecekan menggunakan metode by weight yang memerlukan waktu \pm 2 hari untuk sampel satu mobil=32.4 ton. Sedangkan kebutuhan pasir perusahaan beton berkisar antara 15-20 mobil/hari, sehingga proses penerimaan delivery akan terhambat.
\end{abstract}

Penelitian ini bertujuan untuk membuktikan dan membuat validasi dengan metode pengecekan alternative selain by weight yaitu (by volume) sehingga proses pengecekan menjadi lebih cepat dan dampaknya akan mempercepat proses penerimaan delivery dari supplier pasir. Metode yang digunakan adalah regresi linier dengan membuat perbandingan antara pengecekan by weight dengan by volume.

Hasil pengujian regresi linier didapatkan nilai Korelasi, $R=0,95754 \cong 1$, menyatakan korelasi yang sangat kuat. Dengan demikian berarti, variabel pengetesan kadar lumpur pasir dengan metode by volume memiliki hubungan yang sangat kuat terhadap hasil pengetesan kadar lumpur pasir dengan metode by weight. Nilai $R^{2}$ hasil pengetesan kadar lumpur pasir dengan metode by weight $91,69 \%$, sisanya $8,31 \%$ dipengaruhi faktor-faktor lain, seperti; pemilihan dan pengambilan sampel, metode pengerjaan test (human error) dan faktor lingkungan pada saat pengetesan (suhu dan angin. Perbandingan ini membuktikan metode pengecekan by volume dapat dijadikan alternatif untuk mempercepat waktu penerimaan supply pasir dari supplier.

Keywords : Beton, By weight, By Volume, delivery, Regresi linier, Pasir. 


\section{PENDAHULUAN}

Pasir merupakan bahan baku utama yang digunakan pada industri beton dan keberadaanya bergantung kepada sumber daya alam yang tidak bisa diperbaharui, sebagai bahan baku utama maka mutu pasir juga sangat berpengaruh terhadap kekuatan beton seperti pada penelitian sebelumnya "kadar lumpur mempengaruhi terhadap kuat tekan beton, semakin kecil kadar lumpur, maka kuat tekan beton dan berat jenis beton akan semakin tinggi" (Purwanto \& Priastiwi, 2012). Untuk mendapatkan kualitas pasir yang baik maka harus dilakukan pengecekan sesuai standar SNI dengan metode by weight, dan memerlukan waktu \pm 2 hari untuk sampel satu mobil=32.4 ton.

Faktor pertumbuhan industri seperti pengembangan kawasan industri KIIC, Suryacipta City of Industry, KIM dan kawasan industri lainnya, membuat kebutuhan akan bahan bangunan meningkat sehingga banyak industri beton yang berdiri di Karawang, baik berupa pabrikan komponen beton maupun penjualan beton ready-mix. Kedua produk tersebut membutuhkan material pasir sebagai raw material utama dalam proses pembuatanya.

Proses pengecekan pada penerimaan supply pasir yang selama ini dilakukan hanya pada pengujian pertama dan periodikal untuk satu sampel awal dan selanjutnya secara periodik dilakukan pengecekan ulang, sehingga tidak semua ritase truk dicek satu persatu. Hal ini dapat menyebabkan kualitas pasir menjadi fluktuatif. Proses pengecekan by weight dengan mengikuti standar SNI dan ASTM yang selama ini dilakukan memerlukan waktu \pm 2 hari untuk satu sampel, sehingga tidak memungkinkan setiap ritase truk pasir dilakukan pengecekan setiap harinya. Untuk itu diperlukan metoda penerimaan supply pasir yang lebih cepat dan mudah untuk setiap ritase truk pasir dengan membuat perbandingan antara pengecekan by weight dengan standar SNI dan ASTM terhadap metode pengecekan by volume dengan menggunakan metode korelasi.

\section{Rumusan Masalah}

Rumusan permasalahan berdasarkan latar belakang di atas, pada penelitian ini adalah:

1. Bagaimana cara membandingkan metode pengecekan by weight dan by volume dengan metode regresi linier.

2. Bagaimana mempercepat waktu pengecekan pasir menggunakan metode by volume sebagai alternatif.

\section{Tujuan Penelitian}

Tujuan yang ingin dihasilkan dari penelitian ini adalah:

1. Untuk membuat perbandingan antara metode pengecekan pasir by weight dan by volume dengan metode regresi linier. 
2. Untuk mengurangi waktu pengecekan pasir dengan metode by weight dan menggunakan metode by volume sebagai alternatif untuk mempercepat proses penerimaan pasir dari .

\section{TINJAUAN PUSTAKA}

\section{Korelasi dan Regresi Linier Sederhana}

"Istilah regresi pertama kali diperkenalkan oleh Sir Francis Galton pada tahun 1886. Galton menemukan adanya tendensi bahwa orang tua yang memiliki tubuh tinggi, memiliki anak-anak yang tinggi pula dan orang tua yang pendek memiliki anak-anak yang pendek pula". Sehingga, Galton mengamati "ada kecenderungan bahwa tinggi anak bergerak menuju rata-rata tinggi populasi secara keseluruhan". Interpretasi modern mengenai regresi agak berlainan dengan regresi versi Galton. "Secara umum analisis regresi pada dasarnya adalah studi mengenai ketergantungan variabel dependen (terikat) dengan satu atau lebih variabel independen (variabel penjelas/bebas), dengan tujuan untuk mengestimasi dan/atau memprediksi rata-rata populasi atau nilai rata-rata variabel dependen berdasarkan nilai variabel independen yang diketahui" (Gujarati, 2003).

\section{A. Regresi vs Korelasi}

Menurut Sugiyono (2018), “ analisis korelasi digunakan untuk mencari arah dan kuatnya hubungan antara dua variabel atau lebih, baik hubungan yang bersifat simetris, kausal dan reciprocal, sedangkan analisis regresi digunakan untuk memprediksikan seberapa jauh perubahan nilai variabel dependen, bila nilai variabel independen di manipulasi/dirubah-rubah atau dinaik turunkan”.

\section{B. Korelasi}

"Korelasi menyatakan derajat hubungan antara dua variabel tanpa memperhatikan variabel mana yang menjadi peubah. Karena itu hubugan korelasi belum dapat dikatakan sebagai hubungan sebab akibat".

\section{Jika Korelasi Positif (+)}

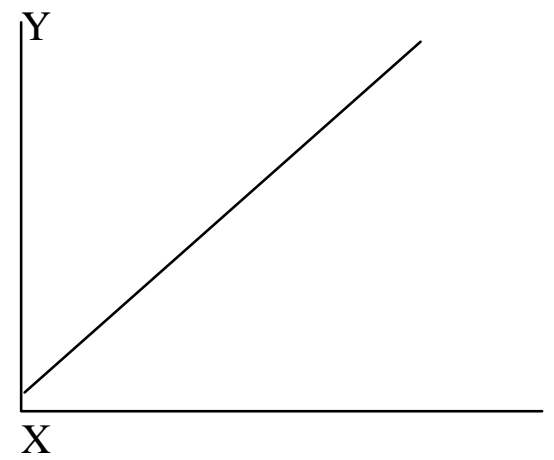

2. Jika Korelasi Negatif (-)

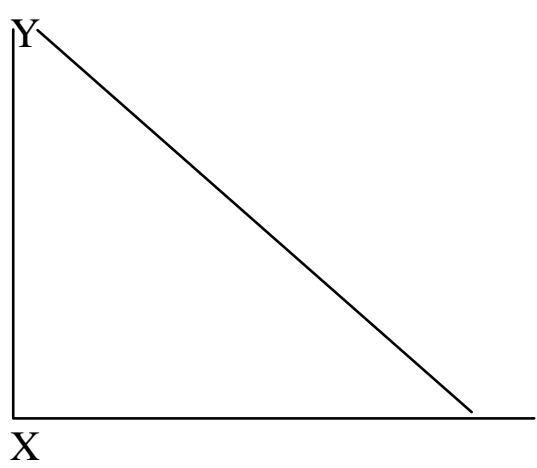

Gambar 2.1 Bentuk Hubungan Korelasi 


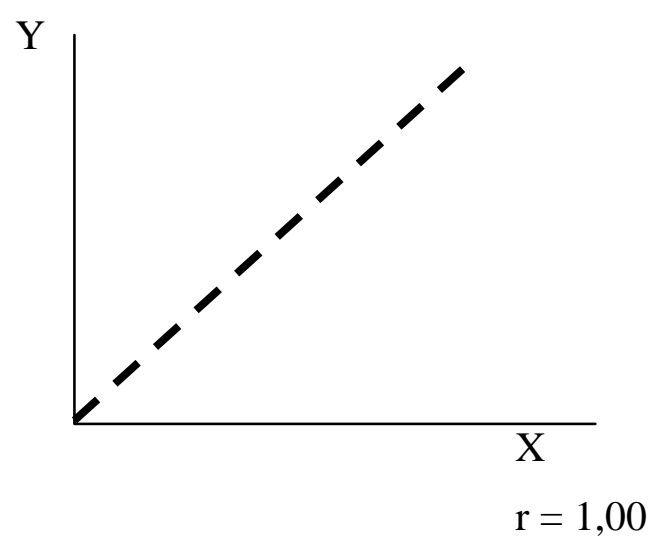

Gambar 2.2 Kekuatan Hubungan Korelasi

Keterangan :

a. Jika semakin besar nilai $\mathrm{X}$, diikuti pula perubahan dengan semakin besar nilai Y, maka Hubungan positif (+)

b. Jika semakin besar nilai $\mathrm{X}$, diikuti pula perubahan dengan semakin kecil nilai Y, Hubungan negatif (-)

c. Jika ( $r=1,00$ hubungan yang sempurna kuat); Jika $r=0,50$, hubungan sedang); dan jika ( $r=0,00$ tidak ada hubungan sama sekali) (dua variabel saling tidak berhubungan).

Tabel 2.1 Teknik Korelasi

\begin{tabular}{|c|l|l|}
\hline No. & Tingkat Skala Pengukuran & \multicolumn{1}{c|}{ Teknik Korelasi } \\
\hline 1. & $\bullet$ Data Nominal & $\bullet$ Koefisien Kontingensi \\
\hline 2. & $\bullet$ Data Ordinal & $\begin{array}{l}\text { a) Spearman Rank } \\
\text { b) Kendal } \tau(\text { tau })\end{array}$ \\
\hline 3. & $\bullet$ Data Interval dan Rasio & $\begin{array}{l}\text { a) Pearson Product Moment } \\
\text { b) Korelasi Ganda } \\
\text { c) Korelasi Parsial }\end{array}$ \\
\hline
\end{tabular}

"Korelasi Product Moment"

$$
\text { Rumus }: r=\frac{n\left(\sum x y\right)-\left(\sum x\right) \cdot\left(\sum y\right)}{\sqrt{n\left(\sum x^{2}\right)-\left(\sum x\right)^{2}} \sqrt{n\left(\sum y^{2}\right)-\left(\sum y\right)^{2}}}
$$

Ket:

$$
\begin{aligned}
& r_{x y}=\text { hubungan } X \text { dengan } Y \\
& X=\text { Nilai } X \\
& Y=\text { Nilai } Y
\end{aligned}
$$




\section{Regresi Linier Sederhana}

"Regresi sederhana didasarkan pada hubungan fungsional ataupun kausal satu variabel independen dengan satu variabel dependen. Persamaan umum regresi regresi linier sederhana" adalah sebagai berikut:

$$
Y^{\prime}=a+b X
$$

Dimana:

$\mathrm{Y}=$ Subyek variabel dependen.

$\mathrm{a}=\mathrm{Y}$ ketika $\mathrm{X}=0$ (konstan)

$\mathrm{b}=$ Arah atau koefisien regresi, menunjukkan angka peningkatan ataupun penurunan variabel dependen berdasarkan perubahan variabel independen. Bila (+) arah garis naik, dan bila (-) maka arah garis turun.

$\mathrm{X}=$ Subyek variabel independen dengan nilai tertentu (data nominal atau rangking).

Nilai a dan $b$, dapat dicari menggunakan rumus berikut:

$$
\begin{aligned}
& Y=a+b x \\
& b=\frac{n\left(\sum x y\right)-\left(\sum x\right) \cdot\left(\sum y\right)}{n\left(\sum x^{2}\right)-\left(\sum x\right)^{2}} \\
& a=\frac{\sum y-b \cdot\left(\sum x\right)}{n}
\end{aligned}
$$

\section{Penilaian Goodness of Fit Model}

Ketepatan fungsi regresi sampel dalam menaksir nilai aktual dapat diukur dari Goodness of fit-nya. Secara statistik, setidaknya ini dapat diukur dari nilai koefisien determinasi, nilai statistik F dan nilai statistik t. Perhitungan statistik disebut signifikan secara statistik apabila nilai uji statistiknya berada dalam daerah kritis (daerah dimana Ho ditolak). Sebaliknya disebut tidak signifikan bila nilai uji statistiknya berada dalam daerah dimana Ho diterima.

\section{Koefisien Determinasi}

Koefisien determinasi $\left(\mathrm{R}^{2}\right)$ pada intinya mengukur seberapa jauh kemampuan model dalam menerangkan variasi-variabel dependen. Koefisien determinasi antara 0 dan $1 . \mathrm{R}^{2}=$ kecil berarti kemampuan variabel-variabel independen menjelaskan variasi-variabel dependen amat terbatas. 


\section{Uji Signifikan (Uji t)}

Untuk menguji signifikasi pengaruh variabel $\mathrm{x}$ terhdap y digunakan uji $\mathrm{t}$ dengan rumus sebagai berikut:

Rumus t hitung, adalah:

$$
\mathrm{t}=\mathrm{r} \frac{\mathrm{n}-2}{\sqrt{1-\mathrm{r}}}
$$

Sedangkan $\mathbf{t}$ tabel rumusnya:

\section{t $\alpha$ df (n-2)}

di mana:

$$
\begin{aligned}
& \mathrm{t}=\mathrm{t} \text { hitung } \\
& \mathrm{r}=\text { koef. } \text { korelasi } \\
& \mathrm{n}=\text { total periode }
\end{aligned}
$$

Kriteria pengujian yaitu:

$$
\begin{aligned}
& \mathrm{t} \text { test } \geq \mathrm{t} \text { tabel } \rightarrow \text { Ho diterima } \\
& \mathrm{t} \text { test } \leq \mathrm{t} \text { tabel } \rightarrow \text { Ho ditolak }
\end{aligned}
$$

\section{Beton}

Menurut (SNI 03-2847-2013), "beton adalah campuran antara semen portland atau semen hidraulik lain, agregat halus, agregat kasar dan air dengan atau tanpa bahan tambahan yang membentuk massa padat. Material pembentuk beton tersebut dicampur merata dengan komposisi tertentu menghasilkan suatu campuran yang homogen sehingga dapat dituang dalam cetakan untuk dibentuk sesuai keinginan. Campuran tersebut bila dibiarkan akan mengalami pengerasan sebagai akibat reaksi kimia antara semen dan air yang berlangsung selama jangka waktu panjang atau dengan kata lain campuran beton akan bertambah keras sejalan dengan umurnya. Beton normal adalah beton yang mempunyai berat satuan $2.200 \mathrm{Kg} / \mathrm{m}^{3}$ sampai $2.500 \mathrm{Kg} / \mathrm{m}^{3}$ dan dibuat menggunakan agregat alam yang dipecah maupun tidak dipecah. Beton adalah campuran bahan yang tersusun dari agregat halus (pasir) dan agregat kasar (split), yang mengalami pengikatan secara kimiawi oleh air dan semen dengan membentuk pasta semen. (Mac Gregor,1997). Seiring dengan penambahan umur, beton akan semakin mengeras, dan akan mencapai kekuatan rencana ( $\mathrm{f}^{\prime} \mathrm{c}$ ) pada usia 28 hari. Kecepatan bertambahnya kekuatan beton ini sangat dipengaruhi oleh faktor air semen dan suhu selama perawatan. Untuk memperoleh kekuatan tekan beton yang diinginkan harus dilakukan beberapa tahapan, yaitu pengujian material, mix design, uji slump dan air content untuk beton segar (fresh concrete), selanjutnya pengujian kuat tekan untuk beton keras (hardened concrete)". 


\section{A. Pengaruh Kadar Lumpur (Pasir) dalam Mutu Beton}

"Kadar lumpur agregat normal yang diijinkan (SK SNI S-04-1989-F\&ASTM C142-97) untuk agregat halus (pasir) maksimal 5\% dan untuk agregat kasar (split) maksimal 1\%". Kadar lumpur akan menghalangi penggabungan campuran semen dan agregat karena lumpur tidak dapat bercampur dengan semen.

\section{a. Kandungan Lumpur}

"Lumpur adalah bagian-bagian yang berasal dari agregat alam (kerikil dan pasir) yang dapat melalui ayakan $0,075 \mathrm{~mm}$, dengan berat jenis kurang dari 2.0 t/m3 (SNI 03-4142-1996 \& ASTM C117-95). Bahan-bahan ini adalah bahan yang menyebabkan terganggunya proses pengikatan pada beton serta pengerasan betonnya, selain yang telah kita ketahui, yakni alkali dan sulfat".

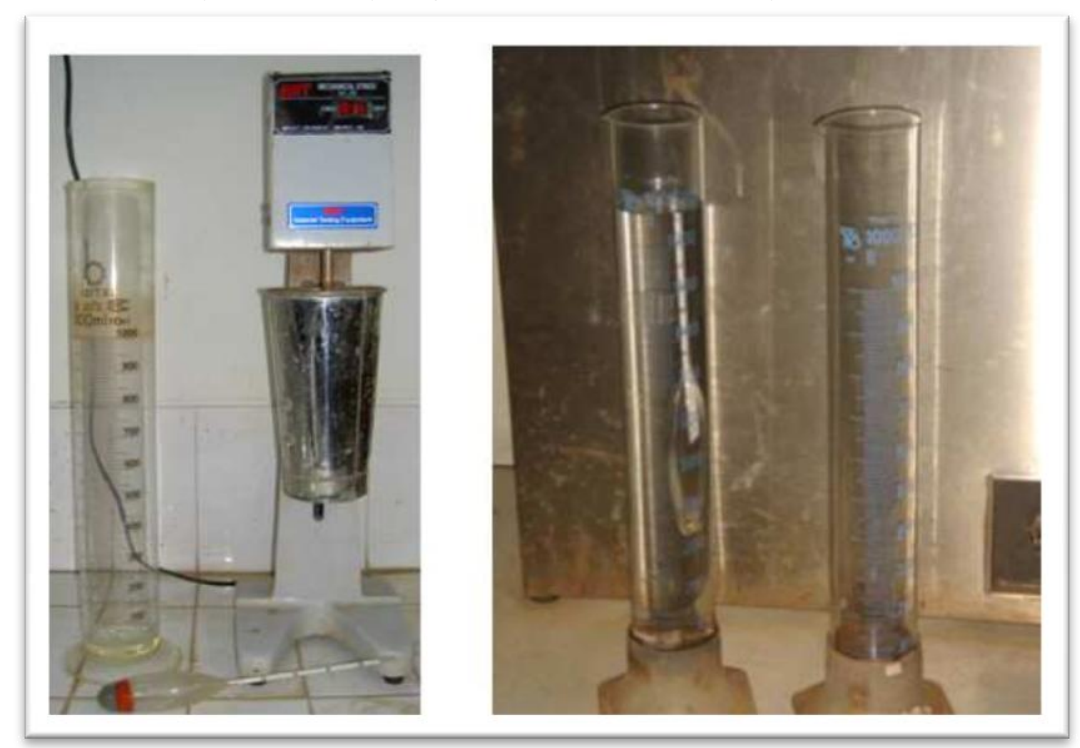

Gambar 2.3 Hidrometer lumpur ukuran agregat halus yang lolos - ayakan $0,0075 \mathrm{~mm}$

Agregat halus adalah bahan yang menyebabkan terganggunya proses pengikatan dan pengerasan beton, selain alkali dan sulfat. Kandungan lumpur yang berlebihan mengurangi daya lekat/ikat agregat dengan semen, membuat kekuatan beton menjadi rendah, sehingga mutu beton tidak tercapai. Pemeriksaan mutu agregat (kerikil maupun pasir) diperlukan agar bahanbahan campuran beton memenuhi syarat, sehingga beton mutunya sesuai dengan standar yang diinginkan. 
"Agregat (kerikil maupun pasir) harus memenuhi syarat mutu sesuai dengan (SK SNI S-04-1989-F \& ASTM C40-99), spesifikasi Bahan Bangunan Bagian A". Salah satu syarat kadar lumpur agregat normal" adalah :

- Agregat Halus (Pasir) : kadar lumpur $\leq 70$ mikro $(0,075 \mathrm{~mm})$ maksimum $5 \%$.

- Agregat Kasar (Split) : kadar lumpur $\leq 70$ mikro (0,075 mm) maksimum $1 \%$.

Untuk mengetahui kandungan lumpur dalam agregat halus menggunakan sistem kocokan, menggunakan gelas ukur yang berisi pasir 130 cc dan air mencapai tinggi 200 cc selama 30 menit. Setelah didiamkan selama plus minus (+ 24 jam), kemudian diamati dan dihitung kandungan lumpurnya dengan rumus :

$$
\begin{gathered}
\mathrm{h}_{1}=\mathrm{h}_{\mathrm{t} 2}-\mathrm{h}_{\mathrm{p}} \\
\text { Kandungan lumpur }=\frac{\mathrm{h}_{1}}{\mathrm{~h}_{\mathrm{t} 1}} \times 100 \% \\
\text { dimana: } \quad \mathrm{h}_{1} \quad=\text { ketinggian lumpur }(\mathrm{cc}) \\
\mathrm{h}_{\mathrm{t} 1} \quad=\text { ketinggian total pasir + lumpur sebelum dikocok } \\
\mathrm{h}_{\mathrm{t} 2}=\text { ketinggian total pasir + lumpur setelah kocokan } \\
\mathrm{h}_{\mathrm{p}}=\text { ketinggian pasir }(\mathrm{cc})
\end{gathered}
$$

Pengecekan kandungan lumpur pada agregat kasar (split) menggunakan sistem pencucian, dengan cara mengambil sampel agregat dan mencucinya. Setelah dicuci, split di oven sampai kering kemudian ditimbang. Kandungan lumpur pada agregat kasar dihitung dengan rumus :

$$
\begin{gathered}
\mathrm{W}_{\mathrm{l}}=\mathrm{W}_{\mathrm{bf}}-\mathrm{W}_{\mathrm{af}} \\
\% \text { Lumpur }=\frac{\mathrm{W}_{\mathrm{l}}}{\mathrm{W}_{\mathrm{bf}}} \times 100 \%
\end{gathered}
$$

dimana: $\quad \mathrm{W}_{1}=$ Berat lumpur $(\mathrm{gr})$

Wbf $=$ Berat agregat sebelum dicuci (gr)

Waf $=$ Berat agregat setelah dicuci $(\mathrm{gr})$

\section{b. Hasil Uji Statistik}

- Pengaruh Kadar Lumpur Terhadap Berat Beton pada tabel 2.2, cukup signifikan dimana semakin bersih beton maka berat beton akan semakin naik. 
Tabel 2.2 Nilai kuat tekan rata-rata pada berbagai variasi

\begin{tabular}{|c|ccc|}
\hline No & Benda Uji & $\begin{array}{r}\text { Berat silinder } \\
\text { rata-rata } \\
\text { (gram) }\end{array}$ & $\begin{array}{c}\text { Kuat Tekan } \\
\text { rata-rata } \\
\text { (MPa) }\end{array}$ \\
\hline 1 & Kadar Lumpur dalam pasir 1\% & 13123,33 & 36,88 \\
\hline 2 & Kadar Lumpur dalam pasir 2\% & 13102,40 & 36,47 \\
\hline 3 & Kadar Lumpur dalam pasir 4\% & 13093,00 & 33,92 \\
\hline 4 & Kadar Lumpur dalam pasir 7\% & 12606,11 & 31,34 \\
\hline 5 & Kadar Lumpur dalam pasir 11 \% & 12524,87 & 31,25 \\
\hline
\end{tabular}

- Pengaruh kadar lumpur terhadap kuat tekan beton dapat dilihat pada gambar 2.4, cukup signifikan di mana semakin bersih beton maka kuat tekan beton akan semakin.

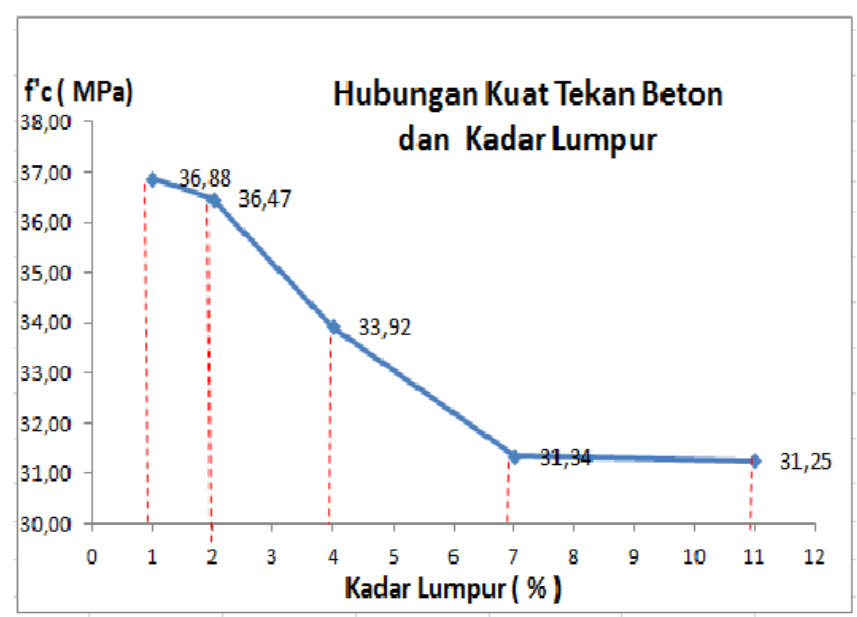

Gambar 2.4 Hubungan kadar lumpur - kuat tekan beton

- Pengaruh kadar lumpur terhadap berat jenis beton, cukup signifikan jika kadar lumpur bersih dibanding sedang dan kotor. dapat dilihat pada gambar 2.5. 


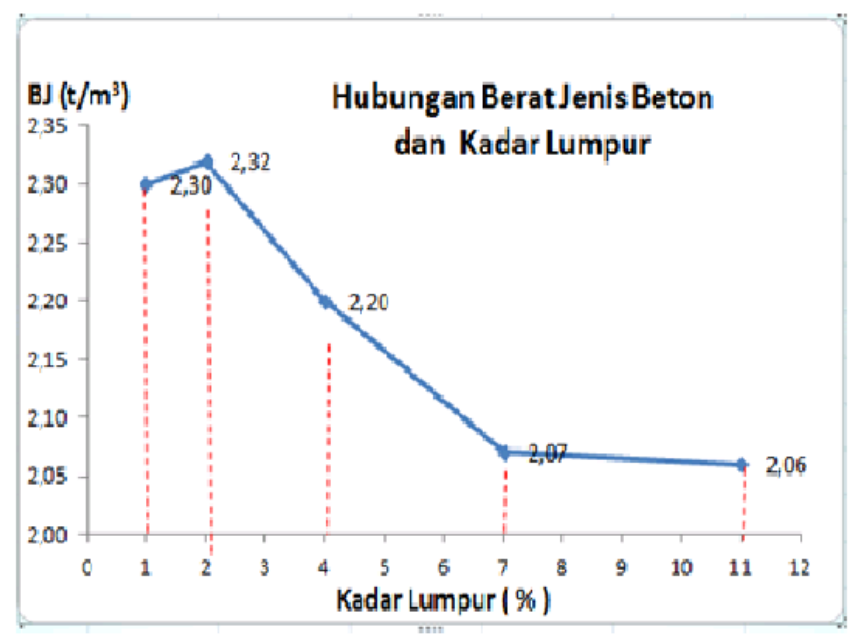

Gambar 2.5 Hubungan kadar lumpur - berat jenis beton

\section{METODOLOGI PENELITIAN}

Metode penelitian menggunakan pendekatan regresi linier dengan membuat perbandingan atau korelasi antara pengecekan pasir menggunakan metode by weight dan metode by volume secara eksperimen di laboratorium. Sumber data pada penelitian ini adalah hasil dari pengetesan kadar lumpur sampel pasir yang datang pada ritase truk setiap hari. Pengambilan dan pengetesan sampel pasir dilakukan secara sengaja oleh Teknisi dan Kepala Laboratorium dengan mempertimbangkan keahlian dan pemahaman responden terhadap objek yang sedang diteliti. Dalam metode korelasi, jumlah sampel yang digunakan adalah 30 data sampel. Merupakan hasil dari pengetesan kadar lumpur dengan metode by weight dan metode by volume.

\section{Kerangka Penelitian}

Alur proses penelitian ini dapat dijelaskan pada diagram alir sebagai berikut:

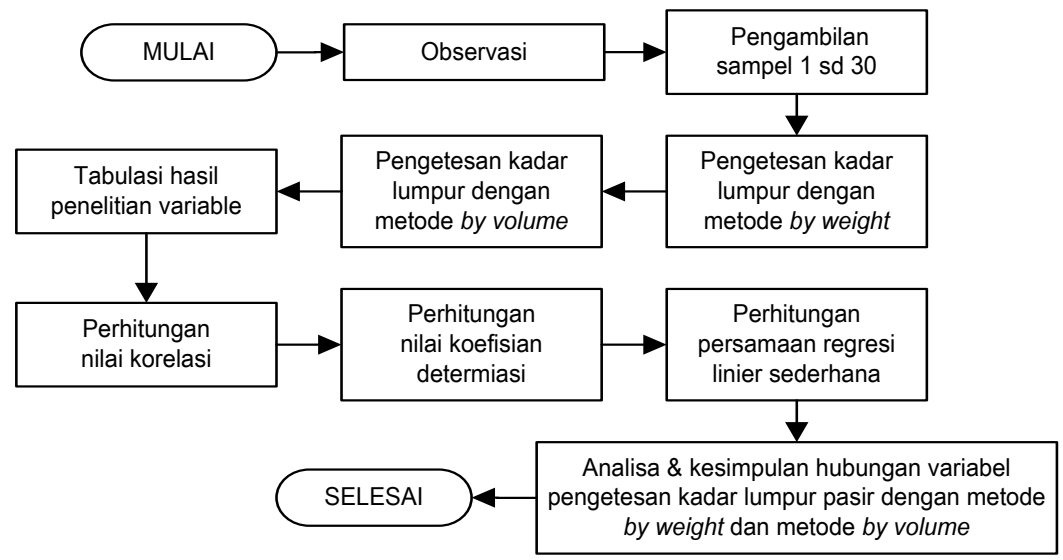

Gambar 3.1 Diagram Alir Penelitian 


\section{HASIL DAN PEMBAHASAN}

\section{Pengumpulan Data}

Data eksperimen material pasir ukuran $<0,075 \mathrm{~mm}$ dengan kandungan lumpur dalam agregat halus yang di ambil dari proses pengecekan 40 sampel pasir di laboratorium, selama satu bulan dari tanggal 04 Januari sampai dengan 01 Maret 2017 dapat dilihat dari tabel 5.1.

Hasil pengecekan pasir kemudian ditabulasi menggunakan rumus regresi linier sehingga dihasilkan nilai $\mathrm{XY}, \mathrm{X}^{2}$ dan $\mathrm{Y}^{2}$, lihat gambar 5.2

a) Data Primer

Data primer diambil dari proses observasi, wawancara dan eksperimen laboratorium di perusahaan beton yang berada di kawasan Suryacipta selama 2 bulan, Januari sampai dengan Februari 2017, melibatkan staff purchasing yang melakukan pembelian pasir dan membuat jadwal kedatangan, karyawan warehouse yang membantu proses pemindahan, supir, dan staff laboratorium yang menangani proses incoming dan quality control penerimaan pasir dari berbagai supplier.

Sampel dari truk yang sama dilakukan pengujian dengan menggunakan metode by weight kemudian dilanjutkan pengujian ke-dua dengan menggunakan metode by volume sehingga dihasilkan persentase lumpur dalam pasir. Selanjutnya dari truk yang berbeda diambil sampel untuk kemudian di lakukan pengujian yang sama, begitu seterusnya. Proses pengecekan dilakukan oleh staff laboratorium yang bertugas untuk membuat laporan apakah pasir yang datang sesuai standar penerimaan atau tidak.

b) Data Sekunder

Data sekunder di dapat dari studi literatur dan standar pengecekan baik SNI dan ASTM, journal dari penelitian-penelitian terdahulu, data perusahaan tentang kebutuhan pasir, kapasitas produksi, tonase truk pasir, data incoming material dari supplier, jadwal kedatangan material beserta identitas supplier. 
Tabel 5.1 Data Hasil Pengujian

Material < 0,075 mm \& Content Of Clay Lumps In Fine Aggregate

\begin{tabular}{|c|c|c|c|c|c|c|c|c|}
\hline \multirow{3}{*}{ No. } & \multirow{3}{*}{ Tanggal } & \multirow{2}{*}{\multicolumn{3}{|c|}{$\begin{array}{c}\text { CLA Y L U M P S ( BY VOLUME) } \\
\begin{array}{c}\text { \% of Material Clay } \\
\text { by Volume }\end{array}\end{array}$}} & \multirow{2}{*}{\multicolumn{3}{|c|}{$\begin{array}{c}\text { CL A Y L U M P S ( BY WEIGHT ) } \\
\text { \% of Material < 0,075 mm } \\
\text { (No. 200) Sieve }\end{array}$}} & \multirow{3}{*}{ Keterangan } \\
\hline & & & & & & & & \\
\hline & & Sample 1 & Sample 2 & Average & Sample 1 & Sample 2 & Average & \\
\hline 1 & O4 Januari 2017 & $8,59 \%$ & $8,26 \%$ & $8,42 \%$ & $4,76 \%$ & $4,23 \%$ & $4,50 \%$ & \\
\hline 2 & O4 Januari 2017 & $6,37 \%$ & $8,42 \%$ & $7,40 \%$ & $3,33 \%$ & $4,44 \%$ & $3,89 \%$ & \\
\hline 3 & 09 Januari 2017 & $8,93 \%$ & $8,76 \%$ & $8,84 \%$ & $5,00 \%$ & $4,67 \%$ & $4,83 \%$ & \\
\hline 4 & 09 Januari 2017 & $7,41 \%$ & $8,09 \%$ & $7,75 \%$ & $3,89 \%$ & $4,44 \%$ & $4,17 \%$ & \\
\hline 5 & 11 Januari 2017 & $8,09 \%$ & $8,59 \%$ & $8,34 \%$ & $4,33 \%$ & $4,67 \%$ & $4,50 \%$ & \\
\hline 6 & 11 Januari 2017 & $7,41 \%$ & $8,26 \%$ & $7,83 \%$ & $3,89 \%$ & $4,44 \%$ & $4,17 \%$ & \\
\hline 7 & 13 Januari 2017 & $8,26 \%$ & $7,75 \%$ & $8,00 \%$ & $4,44 \%$ & $4,17 \%$ & $4,31 \%$ & \\
\hline 8 & 13 Januari 2017 & $8,76 \%$ & $8,59 \%$ & $8,68 \%$ & $4,80 \%$ & $4,67 \%$ & $4,73 \%$ & \\
\hline 9 & 16 Januari 2017 & $8,26 \%$ & $8,93 \%$ & $8,59 \%$ & $4,44 \%$ & $5,00 \%$ & $4,72 \%$ & \\
\hline 10 & 16 Januari 2017 & $7,24 \%$ & $7,58 \%$ & $7,41 \%$ & $3,89 \%$ & $4,17 \%$ & $4,03 \%$ & \\
\hline 11 & 18 Januari 2017 & $8,76 \%$ & $7,92 \%$ & $8,34 \%$ & $4,72 \%$ & $4,44 \%$ & $4,58 \%$ & \\
\hline 12 & 18 Januari 2017 & $8,42 \%$ & $8,26 \%$ & $8,34 \%$ & $4,67 \%$ & $4,33 \%$ & $4,50 \%$ & \\
\hline 13 & 20 Januari 2017 & $8,59 \%$ & $8,09 \%$ & $8,34 \%$ & $4,72 \%$ & $4,56 \%$ & $4,64 \%$ & \\
\hline 14 & 20 Januari 2017 & $8,42 \%$ & $8,26 \%$ & $8,34 \%$ & $4,67 \%$ & $4,40 \%$ & $4,53 \%$ & \\
\hline 15 & 23 Januari 2017 & $8,09 \%$ & $8,09 \%$ & $8,09 \%$ & $4,47 \%$ & $4,40 \%$ & $4,43 \%$ & \\
\hline 16 & 23 Januari 2017 & $8,59 \%$ & $8,93 \%$ & $8,76 \%$ & $4,72 \%$ & $5,00 \%$ & $4,86 \%$ & \\
\hline 17 & 25 Januari 2017 & $8,76 \%$ & $8,26 \%$ & $8,51 \%$ & $4,80 \%$ & $4,40 \%$ & $4,60 \%$ & \\
\hline 18 & 25 Januari 2017 & $8,09 \%$ & $7,92 \%$ & $8,00 \%$ & $4,47 \%$ & $4,40 \%$ & $4,43 \%$ & \\
\hline 19 & 27 Januari 2017 & $8,76 \%$ & $8,26 \%$ & $8,51 \%$ & $4,83 \%$ & $4,67 \%$ & $4,75 \%$ & \\
\hline 20 & 27 Januari 2017 & $8,59 \%$ & $8,76 \%$ & $8,68 \%$ & $4,67 \%$ & $4,80 \%$ & $4,73 \%$ & \\
\hline 21 & 30 Januari 2017 & $9,09 \%$ & $8,09 \%$ & $8,59 \%$ & $5,00 \%$ & $4,44 \%$ & $4,72 \%$ & \\
\hline 22 & 30 Januari 2017 & $7,92 \%$ & $7,75 \%$ & $7,83 \%$ & $4,33 \%$ & $4,13 \%$ & $4,23 \%$ & \\
\hline 23 & 01 Februari 2017 & $8,93 \%$ & $8,26 \%$ & $8,59 \%$ & $4,89 \%$ & $4,61 \%$ & $4,75 \%$ & \\
\hline 24 & 01 Februari 2017 & $8,59 \%$ & $8,76 \%$ & $8,68 \%$ & $4,72 \%$ & $4,89 \%$ & $4,81 \%$ & \\
\hline 25 & 03 Februari 2017 & $9,09 \%$ & $8,09 \%$ & $8,59 \%$ & $4,89 \%$ & $4,44 \%$ & $4,67 \%$ & \\
\hline 26 & O3 Februari 2017 & $8,42 \%$ & $8,26 \%$ & $8,34 \%$ & $4,56 \%$ & $4,67 \%$ & $4,61 \%$ & \\
\hline 27 & 06 Februari 2017 & $8,09 \%$ & $7,92 \%$ & $8,00 \%$ & $4,50 \%$ & $4,44 \%$ & $4,47 \%$ & \\
\hline 28 & 08 Februari 2017 & $6,37 \%$ & $6,54 \%$ & $6,45 \%$ & $3,50 \%$ & $3,40 \%$ & $3,45 \%$ & \\
\hline 29 & 13 Februari 2017 & $6,89 \%$ & $6,72 \%$ & $6,80 \%$ & $3,80 \%$ & $3,67 \%$ & $3,73 \%$ & \\
\hline 30 & 16 Februari 2017 & $7,24 \%$ & $7,41 \%$ & $7,32 \%$ & $4,00 \%$ & $3,80 \%$ & $3,90 \%$ & \\
\hline 31 & 20 Februari 2017 & $6,72 \%$ & $6,02 \%$ & $6,37 \%$ & $3,67 \%$ & $3,33 \%$ & $3,50 \%$ & \\
\hline 32 & 20 Februari 2017 & $7,24 \%$ & $7,41 \%$ & $7,32 \%$ & $4,00 \%$ & $3,80 \%$ & $3,90 \%$ & \\
\hline 33 & 22 Februari 2017 & $6,54 \%$ & $7,24 \%$ & $6,89 \%$ & $3,60 \%$ & $4,00 \%$ & $3,80 \%$ & \\
\hline 34 & 22 Februari 2017 & $7,58 \%$ & $9,09 \%$ & $8,33 \%$ & $4,00 \%$ & $5,20 \%$ & $4,60 \%$ & \\
\hline 35 & 24 Februari 2017 & $9,26 \%$ & $8,09 \%$ & $8,67 \%$ & $5,00 \%$ & $4,40 \%$ & $4,70 \%$ & \\
\hline 36 & 24 Februari 2017 & $7,24 \%$ & $7,06 \%$ & $7,15 \%$ & $4,00 \%$ & $3,80 \%$ & $3,90 \%$ & \\
\hline 37 & 27 Februari 2017 & $8,26 \%$ & $7,58 \%$ & $7,92 \%$ & $4,40 \%$ & $4,00 \%$ & $4,20 \%$ & \\
\hline 38 & 27 Februari 2017 & $6,19 \%$ & $6,72 \%$ & $6,45 \%$ & $3,40 \%$ & $4,80 \%$ & $4,10 \%$ & \\
\hline 39 & O1 Maret 2017 & $7,75 \%$ & $7,58 \%$ & $7,66 \%$ & $4,00 \%$ & $4,20 \%$ & $4,10 \%$ & \\
\hline 40 & 01 Maret 2017 & $7,06 \%$ & $6,89 \%$ & $6,98 \%$ & $4,00 \%$ & $3,60 \%$ & $3,80 \%$ & \\
\hline & & & & & & & & \\
\hline
\end{tabular}

\section{Perhitungan Korelasi dan Regresi Linear Sederhana}

Tabulasi hasil penelitian variabel pengetesan kadar lumpur pasir dengan metode by volume dan metode by weight diperoleh data sebagai berikut: 
Tabel 5.2 Pengolahan Data Kadar Lumpur Pasir

\begin{tabular}{|c|c|c|c|c|c|}
\hline \multirow{2}{*}{$\begin{array}{c}\text { Data } \\
\mathbf{n} \\
\end{array}$} & \multirow{2}{*}{$\begin{array}{l}\text { CLAY LUMPS } \\
\text { (By Volume) } \\
x\end{array}$} & \multirow{2}{*}{$\begin{array}{c}\text { CLAY LUMPS } \\
\text { (By Weight) }\end{array}$} & \multicolumn{3}{|c|}{ Pengolahan Data } \\
\hline & & & $\mathbf{X Y}$ & $x^{2}$ & $Y^{2}$ \\
\hline 1 & 8,42 & 4,50 & 37,89 & 70,97 & 20,23 \\
\hline 2 & 7,40 & 3,89 & 28,76 & 54,70 & 15,12 \\
\hline 3 & 8,84 & 4,83 & 42,74 & 78,18 & 23,36 \\
\hline 4 & 7,75 & 4,17 & 32,28 & 60,03 & 17,36 \\
\hline 5 & 8,34 & 4,50 & 37,53 & 69,56 & 20,25 \\
\hline 6 & 7,83 & 4,17 & 32,63 & 61,34 & 17,36 \\
\hline 7 & 8,00 & 4,31 & 34,46 & 64,05 & 18,54 \\
\hline 8 & 8,68 & 4,73 & 41,07 & 75,27 & 22,40 \\
\hline 9 & 8,59 & 4,72 & 40,57 & 73,81 & 22,30 \\
\hline 10 & 7,41 & 4,03 & 29,83 & 54,86 & 16,22 \\
\hline 11 & 8,34 & 4,58 & 38,22 & 69,54 & 21,01 \\
\hline 12 & 8,34 & 4,50 & 37,53 & 69,57 & 20,25 \\
\hline 13 & 8,34 & 4,64 & 38,69 & 69,56 & 21,52 \\
\hline 14 & 8,34 & 4,53 & 37,81 & 69,57 & 20,55 \\
\hline 15 & 8,09 & 4,43 & 35,86 & 65,42 & 19,65 \\
\hline 16 & 8,76 & 4,86 & 42,58 & 76,72 & 23,63 \\
\hline 17 & 8,51 & 4,60 & 39,14 & 72,39 & 21,16 \\
\hline 18 & 8,00 & 4,43 & 35,48 & 64,06 & 19,65 \\
\hline 19 & 8,51 & 4,75 & 40,41 & 72,39 & 22,56 \\
\hline 20 & 8,68 & 4,73 & 41,07 & 75,27 & 22,40 \\
\hline 21 & 8,59 & 4,72 & 40,56 & 73,78 & 22,30 \\
\hline 22 & 7,83 & 4,23 & 33,16 & 61,37 & 17,92 \\
\hline 23 & 8,59 & 4,75 & 40,81 & 73,81 & 22,56 \\
\hline 24 & 8,68 & 4,81 & 41,69 & 75,27 & 23,09 \\
\hline 25 & 8,59 & 4,67 & 40,08 & 73,78 & 21,78 \\
\hline 26 & 8,34 & 4,61 & 38,46 & 69,57 & 21,26 \\
\hline 27 & 8,00 & 4,47 & 35,79 & 64,06 & 20,00 \\
\hline 28 & 6,45 & 3,45 & 22,27 & 41,66 & 11,90 \\
\hline 29 & 6,80 & 3,73 & 25,40 & 46,28 & 13,94 \\
\hline 30 & 7,32 & 3,90 & 28,55 & 53,60 & 15,21 \\
\hline 31 & 6,37 & 3,50 & 22,28 & 40,52 & 12,25 \\
\hline 32 & 7,32 & 3,90 & 28,55 & 53,60 & 15,21 \\
\hline 33 & 6,89 & 3,80 & 26,18 & 47,46 & 14,44 \\
\hline 34 & 8,33 & 4,60 & 38,34 & 69,47 & 21,16 \\
\hline 35 & 8,67 & 4,70 & 40,76 & 75,20 & 22,09 \\
\hline 36 & 7,15 & 3,90 & 27,88 & 51,11 & 15,21 \\
\hline 37 & 7,92 & 4,20 & 33,25 & 62,69 & 17,64 \\
\hline 38 & 6,45 & 4,10 & 26,46 & 41,65 & 16,81 \\
\hline 39 & 7,66 & 4,10 & 31,42 & 58,73 & 16,81 \\
\hline 40 & 6,98 & 3,80 & 26,51 & 48,67 & 14,44 \\
\hline Jumlah & 318,11 & 173,85 & $1.392,98$ & $2.549,56$ & 761,57 \\
\hline
\end{tabular}


Tabulasi hasil penelitian variabel pengetesan kadar lumpur pasir dengan metode by volume dan metode by weight diperoleh data sebagai berikut:

$\mathrm{n}=$ jumlah data

$\mathrm{X}=$ Nilai variabel $\mathrm{X}$, kadar lumpur dengan metode by volume

$\mathrm{Y}=$ Nilai variabel $\mathrm{Y}$, kadar lumpur dengan metode by weight

Perhitungan hasil penelitian variabel pengetesan kadar lumpur pasir dengan metode by volume dan metode by weight dilakukan untuk menghasilkan;

\section{A. Nilai Korelasi dan Koefisian Determiasi}

Analisis Korelasi:

$$
\mathrm{R}=\frac{\mathrm{n}\left(\sum \mathrm{xy}\right)-\left(\sum \mathrm{x}\right) \cdot\left(\sum \mathrm{y}\right)}{\sqrt{\mathrm{n}\left(\sum \mathrm{x}^{2}\right)-\left(\sum \mathrm{x}\right)^{2}} \sqrt{\mathrm{n}\left(\sum \mathrm{y}^{2}\right)-\left(\sum \mathrm{y}\right)^{2}}}
$$

Keterangan:

$$
\begin{aligned}
& R_{x y} \quad=\text { Hubungan variabel } X \text { dengan variabel } Y \\
& X=\text { Nilai variabel } X \\
& Y=\text { Nilai variabel } Y \\
& R=\frac{(40 \times 1.392,98)-(318,11 \times 173,85)}{\sqrt{(40 \times 2.549,56)-318,11^{2}} \sqrt{(40 \times 761,57)-173,85^{2}}} \\
& R=0,957540542084541 \cong 0,95754
\end{aligned}
$$

Koefisien Determinasi:

$$
\mathrm{R}^{2}=\mathrm{R} \times \mathrm{R}
$$

Keterangan:

$$
\begin{aligned}
& \mathrm{R}^{2}=\text { Koefisien Determinasi } \\
& \mathrm{R}=\text { Korelasi variabel } \mathrm{X} \text { dengan variabel } \mathrm{Y} \\
& \mathrm{R}^{2}=0,95754 \times 0,95754 \\
& \mathrm{R}^{2}=0,9168828516 \cong 0,9169
\end{aligned}
$$

\section{B. Persamaan Regresi Linier Sederhana}

Persamaan Regresi:

$$
\mathrm{Y}=\mathrm{a}+\mathrm{bX}
$$




$$
\begin{gathered}
b=\frac{n\left(\sum x y\right)-\left(\sum x\right) \cdot\left(\sum y\right)}{n\left(\sum x^{2}\right)-\left(\sum x\right)^{2}} \\
b=\frac{(40 \times 1.392,98)-(318,11 \times 173,85)}{(40 \times 2.549,56)-318,11^{2}} \\
b=0,526326528549595 \cong 0,5263 \\
a=\frac{\sum y-b \cdot\left(\sum x\right)}{n} \\
a=\frac{173,85-(0,5263 x 318,11)}{40} \\
a=0,160557846252433 \cong 0,1606
\end{gathered}
$$

Persamaan Regresi:

$$
\begin{gathered}
Y=a+b X \\
Y=0,1606+0,5263 X
\end{gathered}
$$

\section{Analisis dan Hasil Pembahasan}

Analisa hasil perhitungan dan pembahasan penelitian yang diperoleh dari hubungan variabel pengetesan kadar lumpur pasir dengan metode by volume dan metode by weight adalah:

\section{A. Nilai Koefisien Korelasi}

Nilai Koefisien Korelasi yang diperoleh sebesar:

$$
\mathrm{R}=0,957540542084541 \cong 0,95754
$$

Hal ini berarti menyatakan hubungan semakin besar nilai pada variabel pengetesan kadar lumpur pasir dengan metode by volume, diikuti pula perubahan dengan semakin besar nilai pada variabel pengetesan kadar lumpur pasir dengan metode by weight (adanya hubungan positif). Koefesien korelasi ialah pengukuran statistik kovarian atau asosiasi antara dua variabel. Besarnya koefesien korelasi berkisar antara $+1 \mathrm{~s} / \mathrm{d}-1$. Koefisien korelasi menunjukkan kekuatan (strength) hubungan linear dan arah hubungan dua variabel acak. Apabila koefesien korelasi positif (+), maka kedua variabel mempunyai hubungan searah. Artinya yaitu jika nilai variabel $X$ tinggi, maka nilai variabel Y akan tinggi pula. Sebaliknya, jika koefesien korelasi negatif (-), maka kedua variabel mempunyai hubungan terbalik. Artinya jika nilai variabel $\mathrm{X}$ tinggi, maka nilai variabel $\mathrm{Y}$ akan menjadi rendah dan begitu sebaliknya. Untuk memudahkan melakukan interpretasi mengenai kekuatan hubungan antara dua variabel penulis memberikan kriteria sebagai berikut (Sarwono, 2006): 
- 0 : Tidak ada korelasi antara dua variabel

- >0,00-0,25: Korelasi sangat lemah

- $>0,25-0,50$ : Korelasi cukup

- $>0,50-0,75$ : Korelasi kuat

- $>0,75-0,99$ : Korelasi sangat kuat

- 1 : Korelasi sempurna

"Nilai Korelasi, $\mathrm{R}=0,95754 \cong 1$, menyatakan Korelasi yang sangat kuat. Artinya, variabel pengetesan kadar lumpur pasir dengan metode by volume memiliki hubungan yang sangat kuat terhadap hasil pengetesan kadar lumpur pasir dengan metode by weight".

Untuk pengujian dalam SPSS digunakan kriteria sebagai berikut:

- Apabila angka signifikansi hasil riset $<0,05$, maka hubungan kedua variabel signifikan.

- Apabila angka signifikansi hasil riset >0,05, maka hubungan kedua variabel tidak signifikan.

Dari nilai Korelasi, $\mathrm{R}=0,95754$, maka Angka Signifikasi adalah $1-\mathrm{R}=$ 0,04246 , hasil riset $<0,05$, menyatakan hubungan variabel pengetesan kadar lumpur pasir dengan metode by volume terhadap hasil pengetesan kadar lumpur pasir dengan metode by weight memiliki hubungan variabel yang signifikan.

\section{B. Nilai Koefisien Determinasi}

Nilai Koefisien Determinasi yang diperoleh yaitu:

$$
\mathrm{R}^{2}=0,9168828516 \cong 0,9169
$$

Menunjukkan kemampuan variabel pengetesan kadar lumpur pasir dengan metode by volume dalam mempengaruhi variabel hasil pengetesan kadar lumpur pasir dengan metode by weight adalah sebesar 91,69\%, sedangkan sisanya sebesar $8,31 \%$ dipengaruhi atau disebabkan oleh faktor lain, seperti; pemilihan dan pengambilan sampel, metode pengerjaan test (human error) dan faktor lingkungan pada saat pengetesan (suhu dan angin).

\section{Persamaan Regresi}

Persamaan Regresi yang dihasilkan:

$$
\begin{gathered}
Y=a+b X \\
Y=0,1606+0,5263 X \\
a=0,160557846252433 \cong 0,1606 \\
b=0,526326528549595 \cong 0,5263
\end{gathered}
$$

Nilai Konstanta (a) =0,1606 menunjukkan besarnya hasil pengetesan kadar lumpur pasir dengan metode by weight yang sangat dipengaruhi oleh variabel 
pengetesan kadar lumpur pasir dengan metode by volume atau dapat diartikan pada saat nilai variabel pengetesan kadar lumpur pasir dengan metode by volume sebesar 0, maka rata-rata kadar lumpur pasir dengan metode by weight hanya sebesar 0,1606.

Koefisien Regresi (b) sebesar 0,5263 berarti hasil pengetesan kadar lumpur pasir dengan metode by volume mempunyai hubungan positif atau searah dengan ratarata hasil pengetesan kadar lumpur pasir dengan metode by weight, karena koefisien regresi bernilai positif. Hal ini berarti setiap ada peningkatan 1 satuan hasil pengetesan kadar lumpur pasir dengan metode by volume maka akan berpengaruh terhadap hasil pengetesan kadar lumpur pasir dengan metode by weight sebesar 0,5263 satuan. Begitu juga setiap penurunan hasil pengetesan kadar lumpur pasir dengan metode by volume sebesar 1 satuan akan berpengaruh terhadap penurunan rata-rata hasil pengetesan kadar lumpur pasir dengan metode by weight sebesar 0,5263 satuan.

Dengan;

$$
\begin{aligned}
& Y=a+b X \\
& Y=0,1606+0,5263 X
\end{aligned}
$$

Dengan kata lain, apabila metode by volume sebesar $10 \%$, maka hasil pengetesan kadar lumpur pasir dengan metode by weight adalah 5,4236\%. Dan apabila kadar lumpur pasir yang diizinkan metode by weight adalah 5\%, maka hasil pengetesan dengan metode by volume, maksimum $9,1951 \%$. 


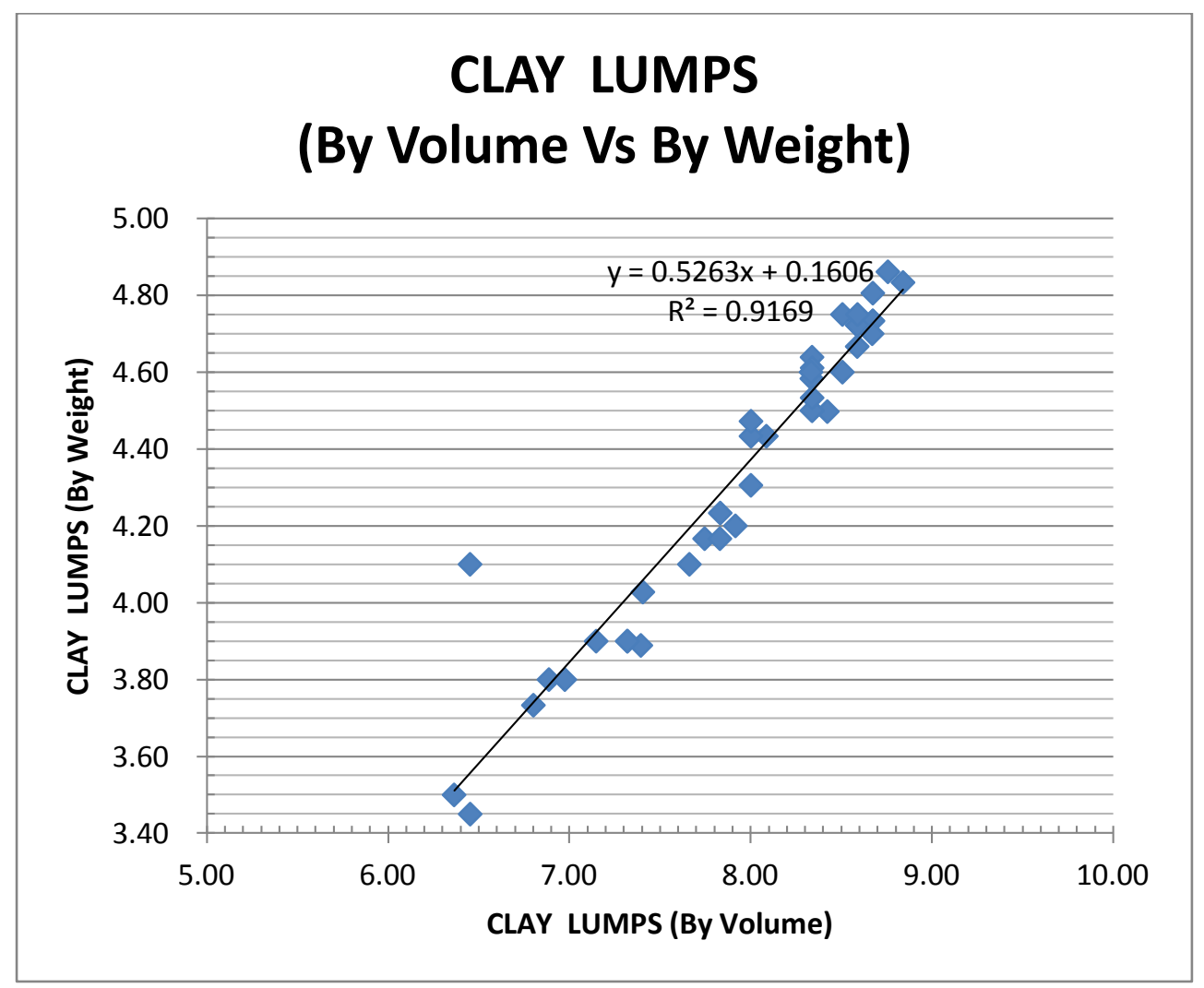

Gambar 5.1 Hubungan Kadar Lumpur Pasir

Metode By Volume Vs By Weight

\section{KESIMPULAN DAN SARAN}

\section{A. Kesimpulan}

Kesimpulan yang dihasilkan dari penelitian hubungan variabel pengetesan kadar lumpur pasir dengan metode by volume dan metode by weight adalah:

1. Hasil analisis dengan menggunakan regresi linier;

a. Nilai Koefisien Korelasi sebesar:

$$
\mathrm{R}=0,957540542084541 \cong 0,95754
$$

Terdapat hubungan positif menyatakan hubungan semakin besar nilai pada variabel pengetesan kadar lumpur pasir dengan metode by volume, diikuti pula perubahan dengan semakin besar nilai pada variabel pengetesan kadar lumpur pasir dengan metode by weight.

- $\quad>0,75-0,99$ : artinya korelasi sangat kuat

Nilai Korelasi, $\mathrm{R}=0,95754$, menyatakan Korelasi yang sangat kuat. Berarti variabel pengetesan kadar lumpur pasir dengan metode by volume memiliki hubungan yang sangat kuat terhadap hasil pengetesan kadar lumpur pasir dengan metode by weight. 
Untuk pengujian dalam SPSS digunakan kriteria sebagai berikut:

- Jika angka hasil riset $<0,05$, maka berarti hubungan kedua variabel signifikan.

Dari nilai Korelasi, $\mathrm{R}=0,95754$, maka Angka Signifikasi adalah $1-\mathrm{R}=$ 0,04246 , hasil riset $<0,05$, menyatakan hubungan variabel pengetesan kadar lumpur pasir dengan metode by volume terhadap hasil pengetesan kadar lumpur pasir dengan metode by weight memiliki hubungan variabel yang signifikan.

b. Nilai Koefisien Determinasi diperoleh sebesar:

$$
\mathrm{R}^{2}=0,9168828516 \cong 0,9169
$$

Kemampuan variabel pengetesan kadar lumpur pasir dengan metode by volume dalam mempengaruhi variabel hasil pengetesan kadar lumpur pasir dengan metode by weight adalah sebesar 91,69\%, sedangkan sisanya sebesar $8,31 \%$ dipengaruhi oleh faktor lain, seperti; pemilihan dan pengambilan sample, metode pengerjaan test (human error) dan faktor lingkungan pada saat pengetesan (suhu dan angin).

c. Persamaan Regresi yang dihasilkan:

$$
\mathrm{Y}=0,1606+0,5263 \mathrm{X}
$$

Setiap peningkatan 1 satuan hasil pengetesan kadar lumpur pasir dengan metode by volume maka akan berpengaruh terhadap hasil pengetesan kadar lumpur pasir dengan metode by weight sebesar 0,5263 satuan. Begitu juga sebaliknya setiap penurunan hasil pengetesan kadar lumpur pasir dengan metode by volume sebesar 1 satuan akan berpengaruh terhadap penurunan rata-rata hasil pengetesan kadar lumpur pasir dengan metode by weight sebesar 0,5263 satuan.

2. Hasil pengujian dengan metode by volume dapat dijadikan alternatif dengan menggunakan metode by weight sehingga dapat mempercepat proses penerimaan supply pasir dari supplier.

\section{B. Saran}

Hasil penelitian di atas dapat dibuktikan bahwa metode korelasi dan regresi dapat diaplikasikan dalam kehidupan \& bidang industri untuk mempermudah dan mempercepat proses pengecekan dan penerimaan pasir. Penulis menyarankan untuk lebih dapat mengaplikasikan secara langsung semua mata kuliah yang kita pelajari ke dalam kehidupan sehari-hari maupun dunia kerja dan industri yang ada disekitar kita. 


\section{DAFTAR PUSTAKA}

ASTM C117-95. Standard Test Method for Materials Finer than 75- $\mu$ m (No. 200) Sieve in Mineral Aggregates by Washing. The American Society for Testing and Materials

ASTM C136-96a. Standard Test Method for Sieve Analysis of Fine and Coarse Aggregates. American Association of State Highway and Transportation Officials Standard AASHTO No. T27

ASTM C142-97. Standard Test Method for Clay Lumps and Friable Particles in Aggregates. American Association of State Highway and Transportation Officials Standard AASHTO No. T112

ASTM C40-99. Standard Test Method for Organic Impurities in Fine Aggregates for Concrete. American Association of State Highway and Transportation Officials Standard AASHTO No. T21.

Kandi, Y.S., Ramang, R., \& Cornelis, R. (2012). Substitusi Agregat Halus Beton Menggunakan Kapur Alam dan Menggunakan Pasir Laut Pada Campuran Beton (Studi Analisis Bahan Kapur Alam dan Pasir Laut dari Kabupaten Sumba Barat Daya Provinsi Nusa Tenggara Timur). Jurnal Teknik Sipil, 1(4).

Pertiwi, D., \& Sucoko, A. (2015). Kuat Tekan Beton Yang Menggunakan Pasir Kadar Lumpur Tinggi Dengan Menambahkan Fly Ash. Seminar Nasional Sains Dan Teknologi Terapan III, Institut Teknologi Adhi Tama Surabaya, ISBN 978-602-98569-1-0.

Purwanto \& Priastiwi, Y.A. (2012). Pengaruh Kadar Lumpur Pada Agregat Halus Dalam Mutu Beton. TEKNIK, 33(2), ISSN 0852-1697

Sadji. Konstruksi Beton I. Fakultas Teknik Sipil dan Perencanaan Institut Teknologi Adhi Tama Surabaya.

SNI 03-4142-1996. Metode Pengujuan Jumlah Bahan dalam agregat yang Lolos Saringan No. 200 (0,075mm). Pusjatan-Balitbang PU.

SNI 2847-2013. (2013). Persyaratan Beton Struktural untuk Bangunan (Tata

Cara Perhitungan Struktur Beton untuk Bangunan Gedung). Badan Standarisasi Nasional (BSN).

Sugiyono. (2018). Statistik Nonparametris Untuk Penelitian. Bandung: Alfabeta. 